\title{
Effect of scrotal insulation on the ability of ram testes to produce testosterone in vitro
}

\author{
S. W. Byers* \\ Reproductive Biology Group, Department of Veterinary Anatomy, University of Queensland, \\ St Lucia, Brisbane, Queensland 4067, Australia
}

\begin{abstract}
Summary. Testosterone production in testis tissue taken from rams that had been scrotally insulated for 28 days and from control animals was compared in the presence and absence of pregnenolone and LH. The absolute content of testosterone, but not its concentration was reduced in scrotally insulated rams. Tissue from treated animals was able to synthesize testosterone from exogenous pregnenolone as effectively as tissue from control rams, whilst $\mathrm{LH}$ and pregnenolone together had little additive effect. The addition of $\mathrm{LH}$ alone stimulated greater testosterone production by testis tissue from treated rams than from control testes. The addition of pregnenolone was followed by a rise in testosterone production within $1 \mathrm{~h}$ of incubation, whilst the LH stimulation of testosterone production was not evident until after $4 \mathrm{~h}$ of incubation. This suggests that the major action of $\mathrm{LH}$ in this system may be to simulate the conversion of pregnenolone precursors to pregnenolone. It is suggested that an accumulation of pregnenolone precursors occurs in the scrotally insulated testes and that these may be mobilized and cleaved after incubation with $\mathrm{LH}$ in vitro.
\end{abstract}

\section{Introduction}

Histological and morphometric examination of testis tissue after artificial cryptorchidism or scrotal insulation suggests that an increase in either the number or volume of Leydig cells occurs (Clegg, 1961 ; Kerr, Rich \& de Kretser, 1979; Byers \& Glover, 1984). Despite this apparent proliferation of steroidogenic tissue, and elevated LH concentrations, peripheral testosterone concentrations are reduced. Heat-damaged testis tissue is less responsive to exogenous (Kerr et al., 1979; Schanbacher, $1980 \mathrm{a})$ and endogenous gonadotrophin stimulation (Byers \& Glover, 1984). Studies involving the measurement of testicular androgen content have also indicated that the androgenic function of the ram and bull testis in vitro is impaired by exposure to elevated temperatures (Skinner \& Rowson, 1968; Gomes, Butler \& Johnson, 1971). The cryptorchid rat testis, however, is hyper-responsive to exogenous gonadotrophin in vitro (de Kretser, Sharpe \& Swanston, 1979; Schanbacher, 1980b; Risbridger, Kerr \& de Kretser, 1981).

The present study investigated the in-vitro basal and gonadotrophin-stimulated testosterone production by tissue taken from the testes of the control and scrotally insulated rams used by Byers \& Glover (1984). By carrying out incubations with and without an androgen precursor, it was hoped to determine which, if any, steps in the steroidogenic pathway to testosterone are affected by scrotal insulation.

* Present address : Department of Anatomy, Georgetown University, Medical and Dental Center, 3900 Reservoir Road, N.W., Washington D.C. 20007, U.S.A.

(C) 1984 Journals of Reproduction \& Fertility Ltd 


\section{Materials and Methods}

After 28-33 days of scrotal insulation (Glover, 1956), 7 treated and 5 control rams were castrated under epidural anaesthesia (lignocaine). Both testes were removed, weighed and about $10 \mathrm{~g}$ testicular tissue were homogenized and extracted with 5 volumes of ethanol. Then $10 \mathrm{~g}$ of the remaining testicular tissue were placed in a sterile glass dish containing Eagles minimum essential medium supplemented with non-essential amino acids and $2 \mathrm{~g}$ sodium bicarbonate/1 (MEM, CSL Laboratories, Brisbane, Australia). This tissue was minced into approximately $1 \mathrm{~mm}$ cubes and about $200 \mathrm{mg}$ were placed into previously weighed incubation tubes. After rinsing twice with MEM the tubes were weighed and then incubated with or without $5 \times 10^{-7}$ M-pregnenolone (Sigma, St Louis, MO, U.S.A.) and $10 \mu \mathrm{g} \mathrm{LH} / \mathrm{ml}$ (NIH-S-20). Incubations were carried out at $33^{\circ} \mathrm{C}$ under an atmosphere of $95 \%$ air and $5 \% \mathrm{CO}_{2}$ in a Buchler vortex evaporator shaking at $100 \mathrm{rev} / \mathrm{min}$. After 1 , 4 and $20 \mathrm{~h}$ all the tubes were centrifuged for $5 \mathrm{~min}$ at $400 \mathrm{~g}$, and the incubation medium was removed and stored at $-20^{\circ} \mathrm{C}$. The tissue was resuspended in appropriate treatment medium and the incubation continued.

Because of the physical difficulties involved and to avoid using pooled tissue which may have given misleading results, tissue from each animal was incubated separately and its response to the various treatments analysed independently. All treatments were carried out in duplicate and the coefficient of variation between duplicates was $15 \%$.

Testosterone was measured in the medium by radioimmunoassay (Byers \& Glover, 1984). Interand intra-assay coefficients of variation were 11.5 and $5.7 \%$ respectively. Recovery of tritiated testosterone from aliquants of incubation medium which had been made up to $100 \mu \mathrm{l}$ with buffer and extracted with diethyl ether was $87.6 \%$.

Most of the data were not normally distributed, and, unless otherwise stated, differences between scrotally insulated and control animals were analysed by the Mann-Whitney $U$ test (Siegel, 1956) for non-parametric data.

\section{Results}

\section{Testis weight and testosterone content}

As shown in Table 1, a marked reduction in the weight of testes of scrotally insulated rams occurred $(P<0.001)$. The absolute content of testosterone but not its concentration was reduced in the testes from scrotally insulated rams. However, individual results were extremely variable, with a range of testosterone concentrations of $0.93-29 \cdot 4 \mu \mathrm{g} /$ testis in the scrotally insulated testes and $1 \cdot 2-$ $63.6 \mu \mathrm{g} /$ testis in the controls.

Table 1. The effect of scrotal insulation and cryptorchidism on testis weight and testosterone content in rams

\begin{tabular}{cccc}
\hline & & \multicolumn{2}{c}{ Testosterone } \\
\cline { 3 - 4 } Rams & $\begin{array}{c}\text { Mean testis weight } \\
(\mathrm{g})\end{array}$ & $\begin{array}{c}\text { Concentration } \\
(\mathrm{ng} / \mathrm{g})\end{array}$ & $\begin{array}{c}\text { Content } \\
(\mu \mathrm{g} / \mathrm{testis})\end{array}$ \\
\hline Treated $(\mathrm{N}=7)$ & $* * 65 \cdot 3 \pm 4 \cdot 9$ & $141 \pm 88.7$ & $7 \cdot 52 \pm 4 \cdot 1$ \\
Control $(\mathrm{N}=5)$ & $138 \cdot \mathrm{c} \pm 7 \cdot 5$ & $129 \pm 78.7$ & $18 \cdot 20 \pm 11 \cdot 5$ \\
\hline
\end{tabular}

Values are mean \pm s.e.m.

Significantly different from control group: ${ }^{* *} P<0.001$ ( $t$ test for 2 means).

\section{In-vitro studies}

The large variation in the testosterone content of testes from individual animals was also found in incubations of minced testis tissue in vitro, and illustrates the importance of measuring basal 
unstimulated production of testosterone. For example, one control and one treated animal had testicular concentrations and basal levels of testosterone in vitro which were 10-20-fold higher than the group median and this suggests that the testes of these animals had been primed with an LH episode just before they were removed. Because of this variation in basal levels, results from each treatment are also expressed as incremental change from the basal level for each animal.

This experiment was not designed to investigate directly the changes in activity of enzymes involved in the biosynthesis of androgen, although an indirect assessment was obtained by measurements of testosterone production from exogenous pregnenolone. There was no difference in the basal secretion of testosterone into the medium by scrotally insulated or control testes when expressed as $\mathrm{ng} / \mathrm{g}$ testis (Table 2) and, although basal secretion from the insulated testes was reduced when expressed per testis, this was not significant. The production of testosterone in the presence of exogenous pregnenolone, with or without LH was greater from the treated tissue on a unit weight basis although not when expressed per testis. After incubation for $1 \mathrm{~h}$ the incremental rise in testosterone production in the presence of pregnenolone was greater in tissue from the scrotally insulated rams $(P<0.025)$ (Text-fig. 1a). In general, therefore, tissue from scrotally insulated rams synthesized testosterone from pregnenolone at least as effectively as did control tissue.

Table 2. The effect of scrotal insulation on testosterone production from minced testis tissue in vitro with or without the addition of $\mathrm{LH}(10 \mu \mathrm{g}-\mathrm{NIH}-\mathrm{S}-20 / \mathrm{ml})$ and pregnenolone $\left(5 \times 10^{-7} \mathrm{M}\right)$

\begin{tabular}{|c|c|c|c|c|c|}
\hline \multirow[b]{3}{*}{ Treatment } & \multirow{3}{*}{$\begin{array}{l}\text { Duration of } \\
\text { incubation } \\
\text { (h) }\end{array}$} & \multicolumn{4}{|c|}{ Testosterone production } \\
\hline & & \multicolumn{2}{|c|}{ Control $(\mathrm{N}=5)$} & \multicolumn{2}{|c|}{ Treated $(\mathbf{N}=7)$} \\
\hline & & $\mathrm{ng} / \mathrm{g}$ & $\mu \mathrm{g} /$ testis & $\mathrm{ng} / \mathrm{g}$ & $\mu \mathrm{g} /$ testis \\
\hline Control (no addition) & $\begin{array}{r}1 \\
4 \\
20\end{array}$ & $\begin{array}{l}77 \cdot 1 \pm 38 \cdot 5 \\
40 \cdot 2 \pm 15 \cdot 2 \\
22 \cdot 3 \pm 7 \cdot 5\end{array}$ & $\begin{array}{r}10.6 \pm 5 \cdot 7 \\
5.4 \pm 2 \cdot 2 \\
2.9 \pm 0.9\end{array}$ & $\begin{array}{l}90 \cdot 7 \pm 57 \cdot 5 \\
48 \cdot 3 \pm 20 \cdot 8 \\
22 \cdot 6 \pm 4 \cdot 41\end{array}$ & $\begin{array}{l}4.78 \pm 2.56 \\
2.78 \pm 1.0 \\
1.37 \pm 0.18\end{array}$ \\
\hline Pregnenolone & $\begin{array}{r}1 \\
4 \\
20\end{array}$ & $\begin{array}{r}95 \cdot 0 \pm 39 \cdot 5 \\
190 \cdot 0 \pm 26 \cdot 1 \\
463 \cdot 0 \pm 64 \cdot 4\end{array}$ & $\begin{array}{l}13 \cdot 0 \pm 5.9 \\
25 \cdot 5 \pm 4 \cdot 71 \\
50.7 \pm 9.73\end{array}$ & $\begin{aligned} 141 \cdot 0 & \pm 65 \cdot 6 \\
\$ 494.0 & \pm 72 \cdot 2 \\
671 \cdot 0 & \pm 135.0\end{aligned}$ & $\begin{array}{l}8.38 \pm 3.23 \\
32.4 \pm 5.91 \\
44.3 \pm 10.6\end{array}$ \\
\hline LH & $\begin{array}{r}1 \\
4 \\
20\end{array}$ & $\begin{array}{l}69 \cdot 1 \pm 38 \cdot 1 \\
33 \cdot 2 \pm 13 \cdot 8 \\
24 \cdot 7 \pm 5 \cdot 6\end{array}$ & $\begin{array}{r}9.56 \pm 5.63 \\
4.57 \pm 2.07 \\
3.3 \pm 1.68\end{array}$ & $\begin{array}{r}77 \cdot 2 \pm 46 \cdot 1 \\
+87.6 \pm 30.9 \\
54 \cdot 7 \pm 15 \cdot 8\end{array}$ & $\begin{array}{l}4 \cdot 13 \pm 2.05 \\
5.54 \pm 1 \cdot 61 \\
3 \cdot 58 \pm 1 \cdot 13\end{array}$ \\
\hline LH + pregnenolone & $\begin{array}{r}1 \\
4 \\
20\end{array}$ & $\begin{array}{r}82 \cdot 5 \pm 32 \cdot 1 \\
203 \cdot 0 \pm 49 \cdot 6 \\
478 \cdot 0 \pm 79 \cdot 3\end{array}$ & $\begin{array}{l}11 \cdot 2 \pm 4.83 \\
26.9 \pm 7.43 \\
61.2 \pm 8.84\end{array}$ & $\begin{aligned} 94.9 & \pm 41.5 \\
+436.0 & \pm 71.0 \\
979.0 & \pm 240.0\end{aligned}$ & $\begin{array}{r}5.0 \pm 1.75 \\
29.8 \pm 5.97 \\
66.1 \pm 17.7\end{array}$ \\
\hline
\end{tabular}

Values are mean \pm s.e.m.

Values significantly different from the control group value: $† P<0.05 ; \ddagger P<0.01$.

After incubation for $1 \mathrm{~h}, \mathrm{LH}$ alone was not able to stimulate testosterone synthesis in control or scrotally insulated tissue. After $4 \mathrm{~h}$ however, a 2.35-fold increase was observed in tissue from experimental animals $(P<0.01)$ but no stimulation was observed in the control tissue (Text-fig. 1b). A small incremental increase in testosterone production in response to $\mathrm{LH}$ was observed in control tissue after $20 \mathrm{~h}$.

\section{Discussion}

The present study demonstrates that, although scrotal insulation results in a decrease in the testicular content of testosterone, testicular tissue from treated rams is more responsive to $\mathrm{LH}$ in vitro. These results are complementary to those of de Kretser et al. (1979), Schanbacher (1980b) and 
(a)

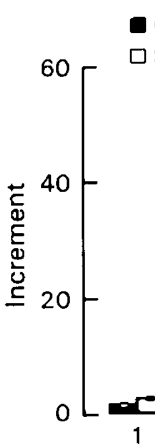

Control

$\square$ Scrotal insulation

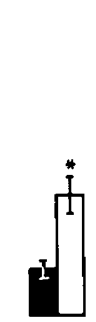

4

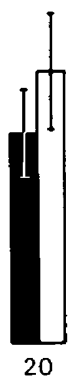

(b)

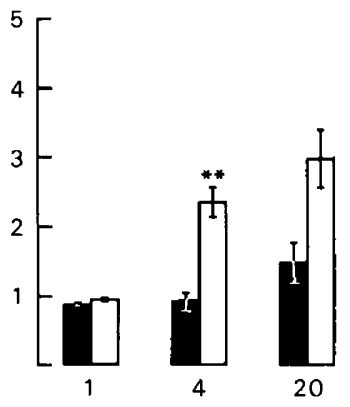

Duration of incubation ( $h$ )

Text-fig. 1. Testosterone production by testicular tissue taken from control $(\mathrm{N}=5)$ and scrotally insulated $(\mathbf{N}=7)$ rams, expressed as increment of basal (no additions) incubation when incubated with (a) $5 \times 10^{-7} \mathrm{M}$-pregnenolone and (b) $10 \mu \mathrm{g} \mathrm{LH} / \mathrm{ml}$. Error bars indicate the s.e.m.

${ }^{*} P<0.025$ compared with control group; ${ }^{* *} P<0.01$ compared with control group.

Risbridger et al. (1981) who showed that testosterone production by testes from cryptorchid rats is hyper-responsive to hCG in vitro. In addition, testicular tissue from treated rams is able to synthesize testosterone from exogenous pregnenolone at least as effectively as can tissue from control animals, whilst $\mathrm{LH}$ and pregnenolone together have no additive effect. The addition of pregnenolone to testicular tissue in vitro resulted in a rise in testosterone production with $1 \mathrm{~h}$ of incubation while the stimulation of testosterone production by LH was not evident until after $4 \mathrm{~h}$ incubation. This suggests that one effect of $\mathrm{LH}$ in this system may be to stimulate the conversion of pregnenolone precursors to pregnenolone (Hall \& Young, 1968). The cleavage of the cholesterol side chain to yield pregnenolone and isocaproate is the rate-limiting step in androgen biosynthesis (Moyle \& Armstrong, 1970) as well as the only reaction that is heat sensitive per se in the testis (Wisner \& Gomes, 1978). This indicates that the hyper-response of tissue from treated rams could be partly due to an accumulation of pregnenolone precursors which could be-mobilized and cleaved in vitro. Esterified cholesterol does accumulate in the testes of cryptorchid rats (Johnson, Gomes \& VanDemark, 1971). Furthermore, this effect of LH is evident when results are expressed as the incremental change from basal, unstimulated values and indicates that it is not due solely to an increase in the relative proportion of interstitial tissue after depletion of the seminiferous epithelium. If the data of de Kretser et al. (1979) and Risbridger et al. (1981) are also expressed as a function of basal (no hCG) stimulation a similar phenomenon is observed: a greater (2-3-fold) incremental increase in testosterone production occurs in response to a fixed dose of hCG in cryptorchid rats than in controls.

It is not possible at this stage to ascertain whether the changes in Leydig cell function in testicular tissue from scrotally insulated rams are a result of a direct temperature-induced impairment of steroidogenesis, or a consequence of a change in the testicular regulation of Leydig cell function by oestradiol (Dufau, Hsueh, Cigorraga, Baukal \& Catt, 1978) or LHRH (Sharpe, Fraser, Cooper \& Rommerts, 1981). It is even more difficult to reconcile the differences between the response of scrotally insulated ram testes in vivo (Byers \& Glover, 1984) with the response of the same testes in vitro. It is unlikely that a temperature-induced lesion of the cholesterol side chaincleavage enzyme could be temporarily relieved during the incubations at scrotal temperature because Risbridger et al. (1981) have reported that a similar increase in responsiveness occurs in cryptorchid rat testes even when they are incubated at $37^{\circ} \mathrm{C}$. It is possible that elevated $\mathrm{LH}$ levels after scrotal insulation may have effected a down regulation of $\mathbf{L H}$ receptors similar to that described by de Kretser et al. (1979), with a consequent reduction in the sensitivity of androgenic response in vivo. However, it is not possible to explain the differences in the response of the testis to 
$\mathrm{LH}$ in vivo and in vitro in terms of receptor loss alone, because it is unlikely that any $\mathrm{LH}$ receptors lost after exposure to elevated LH levels in vivo are regained after removal of the testes. It seems more likely that the removal of the testes and preparation of this tissue for in-vitro studies in some way also removes a factor that is responsible for inhibiting the responsiveness to endogenous LH that occurs in vivo. If this factor were intratesticular, e.g. Sertoli cell LHRH (Sharpe et al., 1981) or Leydig cell oestradiol (Dufau et al., 1978), then mincing and washing of the tissue before incubation may have prevented its action. However, the effects of oestradiol or LHRH on steroidogenesis are thought to involve chronic changes, and it seems unlikely that these changes could be reversed during the relatively short incubations. Setchell \& Sharpe (1981) have shown that exogenous hCG increases the permeability of testicular capillaries, effectively increasing its passage into the lymph fluid bathing the Leydig cells. Sharpe (1983) has now shown that artificial cryptorchidism impairs this mechanism and reduces gonadotrophin uptake by the testis in vivo. This impairment could well explain the discrepancy between the in-vivo and in-vitro responses to LH observed in heatdamaged tissue. Whatever the explanation for these phenomena, it is now clear that elevation of testicular temperature leads to marked changes in Leydig cell structure and function, and can therefore no longer be regarded as specifically affecting those cells within the seminiferous epithelium.

This work was supported by a grant from the Ford Foundation. I thank the NIH for LH and Professor T. D. Glover for comments on this manuscript.

\section{References}

Byers, S.W. \& Glover, T.D. (1984) Effect of scrotal insulation on the pituitary-testicular axis of the ram. J. Reprod. Fert. 71, 23-31.

Clegg, E.J. (1961) Further studies on artificial cryptorchidism: quantitative changes in the interstitial cells of the rat testis. J. Endocr. 21, 433-441.

de Kretser, D.M., Sharpe, R.M. \& Swanston, I.A. (1979) Alterations in steroidogenesis and hCG binding in the cryptorchid rat testis. Endocrinology 105, 135-139.

Dufau, M.L., Hsueh, A.J.H., Cigorraga, S., Baukal, A.J. \& Catt, K.J. (1978) Inhibition of Leydig cell function through hormonal regulatory mechanisms. Int. J. Androl., Suppl. 2, 193-239.

Glover, T.D. (1956) The effect of scrotal insulation and the influence of breeding season upon fructose concentration in the semen of the ram. J. Endocr. 13, $235-242$.

Gomes, W.R., Butler, W.R. \& Johnson, A.D. (1971) Effects of elevated ambient temperature on testis and blood levels and in vitro biosynthesis of testosterone in the ram. J. Anim. Sci. 33, 804-807.

Hall, P.F. \& Young, D.G. (1968) Site of action of trophic hormones upon the biosynthetic pathways to steroid hormones. Endocrinology 82, 559-568.

Johnson, A.D., Gomes, W.R. \& VanDemark, N.L. (1971) Testicular lipids. IV. Effect of unilateral and bilateral cryptorchidism on the fatty acids of esterified cholesterol in the rat and rabbit. J. Reprod. Fert. 25, $425-430$.

Kerr, J.B., Rich, K.A. \& de Kretser, D.M. (1979) Alterations in the fine structure and androgen secretion of the interstitial cells in the experimentally cryptorchid rat testis. Biol. Reprod. 20, 409-422.

Moyle, W.R. \& Armstrong, D.T. (1970) Stimulation of testosterone biosynthesis by luteinizing hormone in transplantable mouse Leydig cell tumours. Steroids 15, 681-693.

Risbridger, G.P., Kerr, J.B. \& de Kretser, D.M. (1981) Evaluation of Leydig cell function and gonadotropin binding in unilateral and bilateral cryptorchidism: evidence for local control of Leydig cell function by the seminiferous tubule. Biol. Reprod. 24, 534-540.

Schanbacher, B.D. (1980a) Androgen response of cryptorchid and intact rams to ovine LH. J. Reprod. Fert. 59, 151-154.

Schanbacher, B.D. (1980b) Androgen secretion and characteristics of testicular hCG binding in cryptorchid rats. J. Reprod. Fert. 59, 145-150.

Setchell, B.P. \& Sharpe, R.M. (1981) Effects of injected human chorionic gonadotrophin on capillary permeability, extracellullar fluid volume and the flow of lymph and blood in the testes of rats. J. Endocr. 91, 245-254.

Sharpe, R.M. (1983) Impaired gonadotrophin uptake in vivo by the cryptorchid rat testis. J. Reprod. Fert. 67, 379-387.

Sharpe, R.M., Fraser, H.M., Cooper, I. \& Rommerts, F.F.G. (1981) Sertoli-Leydig cell communication via an LHRH-like factor. Nature, Lond. 290, 785-787.

Siegel, S. (1956) Non-parametric Statistics for the Behavioral Sciences. McGraw-Hill, New York.

Skinner, J.D. \& Rowson, L.E.A. (1968) Some effects of unilateral cryptorchidism and vasectomy on sexual development of the pubescent ram and bull. $J$. Endocr. 42, 311-321.

Wisner, J.R. \& Gomes, W.R. (1978) Influence of experimental cryptorchidism on cholesterol side chain cleavage enzyme and $\Delta^{5}-17 \beta$-hydroxysteroid dehydrogenase activities in rat testis. Steroids 31, 189-203. 